\title{
LOUIS SIMPSON AND WALT WHITMAN: Destroying the Teacher
}

\author{
HANK LAZER
}

WITH REGARD to recent American poetry, it is easy and fruitful to trace the influence of Walt Whitman. Particularly with the revolution in style that began in the mid-fifties with Allen Ginsberg's Howl and Other Poems and that continued in the early sixties with Robert Bly's Silence in the Snowy Fields, Whitman has been seen as a congenial poetic mentor and model for a wide range of American poets. Ginsberg, for example, was drawn to Whitman for a number of reasons: Whitman's metrics and use of the long line; Whitman's commitment to a bardic, prophetic function for poetry; Whitman's example of a national poet who can speak to (and about) all of America; Whitman's frank sexuality and homoeroticism; and Whitman's fresh use of Biblical language and form. On the other hand, Bly's affinity with Whitman, though perhaps narrower than Ginsberg's, is every bit as central to Bly's own development. As Bly acknowledges in a recent essay, "one cannot imagine The Teeth Mother appearing without Whitman beforehand."1 Bly seizes on the mystical and spiritual dimension in Whitman's poetry, as does Galway Kinnell, though Kinnell seems more drawn than Bly to the tangible, physical side of Whitman's poetry. The democratic impulse in Whitman, his love of individuals of all trades and classes, especially his love of the neglected and dispossessed, can be seen as a strong influence on recent poets such as Philip Levine, David Ignatow, and James Wright. And recently, in Lucky Life and The Red Coal, Whitman's long line has again been used with great success by Gerald Stern, who also makes substantial use of Whitman's catalog technique.

Because of the range, ambition, freedom, and magnitude of Whitman's work, as well as the attractive model of Whitman's persistence as a poet, it is to be expected that nearly every contemporary American poet of some stature will, at one time or another, bow respectfully in Walt Whitman's direction. ${ }^{2}$ Indeed, critics delight in finding Whitman's presence everywhere (as Whitman himself had hoped and predicted at the end of "Song of Myself") until nearly each and every American poet bears some "essential" kinship to him. Harold Bloom, for example, after straining the connection between Stevens and Whitman, waxes hyperbolic by telling us that Stevens "may not be the culmination of Whitman's poetics either, since that begins to seem the peculiar distinction of John Ashbery." 3 The contemporary reader may begin to think that Whitman's Leaves is a large pinhead where all poetic angels live.

The relationship between Louis Simpson and Walt Whitman, however, is neither a tangential one nor a mere bow of respect. In Simpson's poetry 
the reader finds a complex, intelligent, skeptical playing out of affinities with and differences from Whitman's poetry. Though Simpson clearly is drawn to Whitman's work and example, Simpson does not set Whitman up as some remote, perfected poetic model. In a very recent essay, "Honoring Whitman," Simpson begins with an epigraph from "Song of Myself": "He most honors my style who learns under it how to destroy the teacher." The epigraph summarizes the outcome of Simpson's study of Whitman, but their relationship proves more complex and instructive than the epigraph might suggest. By exploring Simpson's relationship to Whitman, we can begin to see certain paradigmatic features emerge, features which are common to any contemporary poet's relationship with Whitman. As Simpson's poetry will demonstrate, to speak to Whitman is to interpret and define who and what Whitman was; to explore what an American poet is; to struggle with a major American poetic influence (as in any engagement with a major precursor); to explore the role of "ordinary life" in poetry; to affirm a liberation of form (not, however, to affirm formless poetry); to evaluate America and the American enterprise; to form a picture of an ideal poet by accepting elements of Whitman and rejecting others; and to consider the peculiarly American problem of a poet's audience and a poet's relationship to the "common man." By tracing Simpson's relationship to Whitman, or, to use Ed Folsom's term, the way that Simpson "talks back" to Whitman, ${ }^{4}$ the shape and development of Simpson's poetry can be described. His encounter with Whitman is pivotal in Simpson's development from an Audenesque, formal, ironic poet into a writer of free verse, dramatic narratives of ordinary life. By Simpson's encounter with Whitman, I do not mean his very first reading of Whitman. Instead, I refer to Simpson's direct dialogue (in poetry and prose) with Whitman, a sustained discussion and argument which begins with Simpson's fourth book of poems, At the End of the Open Road (1963), and which continues, on and off, for the next twenty years, including Simpson's most recent books, The Best Hour of the Night (1983) and People Live Here: Selected Poems 1949-1983.

However, it would be inaccurate to say that Simpson's poetry required this kind of encounter with Whitman before it could begin to address and evaluate America. In $A$ Dream of Governors (1959), Simpson's third book of poems, the second section is entitled "My America." Indeed, Simpson's subsequent judgments of America have not changed fundamentally from the conclusion reached in "To the Western World":

In this America, this wilderness

Where the axe echoes with a lonely sound,

The generations labor to possess

And grave by grave we civilize the ground. ${ }^{5}$ 
The vision of an America which does death's bidding receives more detailed expression in Simpson's next book, At the End of the Open Road (1963), but the attitude expressed is essentially the same one found in "To the Western World." The conclusion to "West," from Simpson's second book of poems, Good News of Death and Other Poems (1955), also demonstrates the steadiness of the poet's attitudes:

\author{
Ranching in Bolinas, that's the life, \\ If you call cattle life. \\ To sit on a veranda with a glass \\ And see the sprinklers watering your land \\ And hear the peaches dropping from the trees \\ And hear the ocean in the redwood trees, \\ The whales of time, \\ Masts of the long voyages of earth, \\ In whose tall branches day \\ Hangs like a Christmas toy. \\ On their red columns drowse \\ The eagles battered at the Western gate; \\ These trees have held the eagles in their state
}

When Rome was still a rumor in the boughs. (GND, 173)

This critique of mellow California living eventually develops into the beginning of "A Friend of the Family": "Once upon a time in California / the ignorant married the inane / and they lived happily ever after" (ADV, 53). The vision of American civilization slipping toward its own undistinguished death recurs directly and indirectly throughout Simpson's poetic career.

So what does change as a result of Simpson's encounter with Whitman? Tone, style, and the actual characters of Simpson's poetry. If we take "Orpheus in America" as representative of his earlier poetry, we find that Simpson entangles himself in an abstract, self-consciously literary language:

\author{
America begins antiquity. \\ Confronted with pure space, my Arcady \\ Has turned to stone. \\ This gazing freedom is the basilisk. \\ O for a mirror! \\ The melancholy of the possible \\ Unmeasures me. (DREAM, 21)
}

What must change is Simpson's tone, for the narrator's voice is too lofty, a learned version of the know-it-all that Simpson will later condemn in Whitman, calling Whitman "the eternal sophomore." Before he can give convincing consideration to the people and objects of ordinary life, Simpson 
must work himself free from the cultured Audenesque voice of American verse of the fifties. In part, his encounter with Whitman serves as a stylistic catalyst.

As one final example of Simpson's early style, the poem "Hot Night on Water Street" illustrates the stiff style and voice that undercut his early work. Simpson, as always, comes up with his characteristically incisive, deflating observation: "Some day, when this uncertain continent / Is marble, and men ask what was the good / We lived by, dust may whisper "Hollywood" (DREAM, 16). In the poem the speaker, a type of Whitman traveler/wanderer, walks along Water Street, offering us a catalog of his observations. Sounding like Hawthorne's Young Goodman Brown, the speaker concludes:

I didn't linger - sometimes when I travel

I think I'm being followed by the Devil.

At the newsstand in the lobby, a cigar

Was talkative: "Since I've been in this town

I've seen one likely woman, and a car

As she was crossing Main Street, knocked her down."

I was a stranger here myself, I said,

And bought the New York Times, and went to bed.

But this poem makes us too aware of its "poetic" effects, including the rhyme scheme. We become aware of the all too literary posture of another tour "through certain half-deserted streets, / The muttering retreats / Of restless nights..."

In Poet's Choice (1962), Simpson chooses to represent his work with the poem "Walt Whitman at Bear Mountain." He selects this particular poem, as he explains, "not because I think it is the best poem I have written, but because it marked a turning point in my work." 6 In part, Simpson has in mind the stylistic relaxation or, more accurately, the exploration of free verse, that he (and many other American poets) experienced in the early sixties. For Simpson, this turning point involves primarily style, but also a slight shift in subject matter:

What I did manage to arrive at in "Walt Whitman" was a poem that presented certain images and ideas in an almost colloquial manner, in lines whose rhythm was determined by my own habits of speech. . . . My groping toward a poetry of significant images and spoken lines enabled me to say certain things that I had not been able to say before. This poem was followed by others in which I was able to deal with material that interested me-poems about history, my own personal life, America. (COMP, 33)

The poem also marks the beginning of Simpson's direct confrontation with Whitman.

"Walt Whitman at Bear Mountain" figures prominently in At the End of 
the Open Road (1963), for which Simpson received the Pulitzer Prize. The book begins and ends with Whitman's presence and influence, the key Whitman-poems being "In California," "On the Lawn at the Villa," "Walt Whitman at Bear Mountain," "Pacific Ideas-a Letter to Walt Whitman," and "Lines Written Near San Francisco." The title of Simpson's book lets us know that we are getting an up-dating of Whitman's journey. We will learn where those who have tramped after Whitman, accepting his offer at the end of "Song of the Open Road": "Camerado, I give you my hand!," have arrived. Simpson aims to show us where Whitman's dream of American expansion ends up. The bleak vision which follows is akin to what Ed Folsom observes in Allen Ginsberg's poetry of the mid-fifties: "Ginsberg here sets the tone of the contemporary American dialogue with Whitman, a dialogue that involves a deep concern with the loss of the Open Road, a loss of American direction, openness, and purpose, and a concomitant loss of love" (MS, xxxxv).

Simpson's opening poem in At the End of the Open Road, "In California," places us at the literal end of that road, at the continent's end; the poem emphasizes fraud, trickery, and death. Simpson's version of California is closer to Thoreau's than to Whitman's. As F. O. Matthiessen observes, "Thoreau did not share Whitman's confidence in mass movements, and said that California was ' 3000 miles nearer to hell,' since its gold was a touchstone that had betrayed 'the rottenness, the baseness of mankind."'7 Simpson's poem establishes the speaker's own gloomy vision; his accurate cynicism will serve as a corrective to Whitman's cheery "epical" optimism. But the speaker also feels a bit guilty for his gloomy vision:

\footnotetext{
Here I am, troubling the dream coast

With my New York face,

Bearing among the realtors

And tennis-players my dark preoccupation.
}

California is seen as a false Mecca, a fool's paradise, and Whitman is viewed as one more huckster, one more confidence man: "Lie back, Walt Whitman, / There, on the fabulous raft with the King and the Duke!" Thus, Simpson lumps Whitman together with the King and the Duke, those Twainian precursors to their mid- and late-twentieth-century brothers, the real estate agents (of Simpson's poem) and our own TV salesmen. Simpson's speaker tells Whitman,

Lie back! We cannot bear

The stars any more, those infinite spaces.

Let the realtors divide the mountain,

For they have already subdivided the valley. 
At the end of the open road, the poet shows us "rectangular city blocks" planned by "the same old city-planner, death," the architect for late-twentiethcentury America.

The speaker of Simpson's American poems, particularly in At the End of the Open Road, sniffs out the rottenness at the heart of America's muscleflexing pride. Even before America's spiritual sickness became an international spectacle during the late sixties and early seventies, Simpson, in his anti-Whitman capacity, sensed that illness. "The Inner Part" offers Simpson's assessment of the American spirit in a characteristically concise, merciless fashion:

\author{
When they had won the war \\ And for the first time in history \\ Americans were the most important people- \\ When the leading citizens no longer lived in their shirt sleeves, \\ And their wives did not scratch in public; \\ Just when they'd stopped saying "Gosh!"- \\ When their daughters seemed as sensitive \\ As the tip of a fly rod, \\ And their sons were as smooth as a V-8 engine- \\ Priests, examining the entrails of birds, \\ Found the heart misplaced, and seeds \\ As black as death, emitting a strange odor. (END, 56)
}

Nine years later in his autobiography, North of famaica, Simpson explains his disagreement with Whitman:

I found Whitman's ideas often intolerable; celebrating progress and industry as ends in themselves was understandable in 1870 , for at that time material expansion was also a spiritual experience, but in the twentieth century the message seemed out of date. The mountains had been crossed, the land had been gobbled up, and industry was turning out more goods than people could consume. Also, the democracy Whitman celebrated, the instinctive rightness of the common man, was very much in doubt. Now we were governed by the rich, and the masses were hopelessly committed to an economy based on war. It was a curious thing that a man could write great poetry and still be mistaken in his ideas. ${ }^{8}$

It would seem that Simpson praises the quality of Whitman's verse while rejecting outright his precursor's vision. But before I overstate (and oversimplify) the nature of Simpson's encounter with Whitman, for he does not merely attack and dismiss Whitman's point of view, I would like to turn to some more general remarks about influence to provide a framework for viewing the interaction between these two poets. Harold Bloom begins his study of poetic influence, The Anxiety of Influence, by noting that "weaker talents 
idealize."9 Clearly, Simpson does not (merely) idealize Whitman. But more important, Bloom suggests that "poetic influence, or as I shall more frequently term it, poetic misprision, is necessarily the study of the life-cycle of the poet-as-poet" (ANX, 7). Such an observation rescues influence-studies from becoming dry, pseudo-objective tracings of calm affinities and genial borrowings. As we shall see, Simpson's relation to Whitman is indeed based, in part, on misprision. That is, Simpson proceeds to read Whitman partially, emphasizing an aspect of Whitman's poetic vision, reacting to and against it so as to develop his own vision. Thus the study of poetic influence, as Bloom correctly asserts, is not a static event, but an unfolding relationship which has very much to do with the poet's (Simpson's) life-cycle or development as a poet. To study Simpson's interaction with Whitman is to bear out Bloom's generality:

We journey to abstract ourselves by fabrication. But where the fabric has already been woven, we journey to unravel. (ANX, 64-65)

In Bloom's theory of influence, the later poet, at some key moment, swerves from the earlier poet and revises or corrects the earlier poet's vision. When we consider Simpson's revision of Whitman's American prophecy, we would do well to bear in mind Bloom's warning:

As the poets swerve downward in time, they deceive themselves into believing they are tougherminded than their precursors. This is akin to that critical absurdity which salutes each new generation of bards as being somehow closer to the common language of ordinary men than the last was. (ANX, 69)

Clearly, there is a tough-minded Whitman to be found. He is not merely a cheerleader shouting for American expansion and progress while always maintaining his own sweet optimism. In Democratic Vistas, for example, Whitman offers the following analysis of America:

I say we had best look our times and lands searchingly in the face, like a physician diagnosing some deep disease. Never was there, perhaps, more hollowness at heart than at present, and here in the United States. Genuine belief seems to have left us. The underlying principles of the States are not honestly believ'd in, (for all this hectic glow, and these melodramatic screamings,) nor is humanity itself believ'd in. What penetrating eye does not everywhere see through the mask? The spectacle is appalling. We live in an atmosphere of hypocrisy throughout. ... I say that our New World democracy, however great a success in uplifting the masses out of their sloughs, in materialistic development, products, and in a certain highly-deceptive superficial popular intellectuality, is, so far, an almost complete failure in its social aspects, and in really grand religious, moral, literary, and esthetic results. ${ }^{10}$ 
Even if we do acknowledge, as does Whitman's most recent biographer, Justin Kaplan, that Whitman "believed that America, for all its troubles, alone possessed the prerequisites for a great moral and religious civilization" and that America's "failures were transitional, growing pains,"11 there is still a Whitman who sees the evil and failings of America. It is this critical, dark Whitman who often gets ignored in contemporary attacks on his views. Simpson is not alone, and indeed Bloom would claim that Simpson's actions typify "the anxiety of influence," when he "misreads" Whitman, taking a major aspect of the poet's vision and acting as if that were all Whitman had to say on the subject. After looking further at Simpson's poems in At the End of the Open Road, an examination of Whitman's own "Song of the Open Road" will provide further evidence of Simpson's pattern of misprision.

In "On the Lawn at the Villa," Simpson's narrator begins to feel a bit guilty for his gloomy vision. Not that he would exchange his own sarcasm for Whitman's gushy optimism; nevertheless, the narrator's irony is at times nearly too much for him to stand:

It's complicated, being an American,

Having the money and the bad conscience, both at the same time.

Perhaps, after all, this is not the right subject for a poem.

Of course, it is the right subject for a poem; but where does this irony and acuity of observation leave the speaker? In this poem, he (and the others) are characterized as "paralyzed." At this point in Simpson's writing, Whitman seems to be an annoyance, a type: the optimistic American proclaiming the greatness of himself and the nation. As such, he is subject only to Simpson's scorn.

However, in spite of Simpson's withering ironies and deflating observations, part of Whitman's spiritual journey is a necessity for Simpson as well, even if his journey is to be, admittedly, through a bleaker world. Even in an ironic context, this stanza from "Love, My Machine" (which occurs shortly after "On the Lawn at the Villa") inherits its breadth and phrasing from Whitman:

For every man and woman

Is an immortal spirit

Trapped and dazed on a star shoot.

The narrator's conclusion offers a variant of Whitman's own journey: "I am going into the night to find a world of my own."

The last three poems in At the End of the Open Road, "Walt Whitman at Bear Mountain," "Pacific Ideas - a Letter to Walt Whitman," and "Lines Written Near San Francisco," all involve Whitman, as to let the reader know that Simpson's earlier posture of sarcasm and scorn proved an insufficient 
dismissal of a figure who turns out to be more compelling than the poet might wish to admit. ${ }^{12}$

In "Walt Whitman at Bear Mountain," Simpson addresses his question to the friendly, but ignored, statue of Whitman. But in his criticisms of Whitman, I also detect a desire on Simpson's part to find or inspire a Whitman who could speak back to him and thus, perhaps, jar the narrator out of his own gloomy vision:

\author{
"Where are you, Walt? \\ The Open Road goes to the used-car lot. \\ Where is the nation you promised?"
}

Simpson wants to drag his predecessor out to see the "real" America of the 1960 s, not the idealized America of Whitman's, at times, inflated rhetoric. Simpson continues, "As for the people-see how they neglect you! / Only a poet pauses to read the inscription," and clearly that poet pauses with considerable skepticism. We should also bear in mind that these remarks are spoken to the poet who concluded the inspired introduction to the first edition of Leaves of Grass by stating, "The proof of a poet is that his country absorbs him as affectionately as he has absorbed it." In "On Being a Poet in America," an essay which begins with an epigraph from Whitman and which was written during the same period as his Whitman-poems, Simpson extends his critique of Whitman's ideal of popular poetry:

"To have great poets we must have great audiences too." This tag from Whitman, which adorns or used to adorn every issue of Poetry, is about as close to the opposite of the truth as you can get. To have great poetry all that is needed is great talent. There can be no such thing as a great audience for poetry. An audience for bad writing-yes!13

Not only has the Whitman in Simpson's poem failed to achieve the audience he had hoped for, but the reply that Whitman makes to his question in Simpson's poem is unsatisfactory. Simpson's Whitman is a diminished Whitman, a poet whose self may no longer be universal or representative, a poet who now explains that his prophecies were in fact merely "moods." He is the huckster unmasked, which leaves Simpson alone to confront the great American ruin:

Then all the realtors,

Pickpockets, salesmen, and the actors performing

Official scenarios,

Turned a deaf ear, for they had contracted

American dreams. 
The poet wishes for a Whitman who might somehow counter his contemporary vision of an America which, as At the End of the Open Road began by explaining in the opening poem "In California," does death's bidding. In the final poem of the book, "Lines Written Near San Francisco," Simpson's bitter conclusion is:

\author{
We must remain, to serve the returning sun, \\ And to set tables for death. \\ For we are the colonists of Death- \\ Not, as some think, of the English. \\ And we are preparing thrones for him to sit, \\ Poems to read, and beds \\ In which it may please him to rest.
}

Ronald Moran claims that "Walt Whitman at Bear Mountain" "is more than an engaging celebration; it is a serious indictment of the American condition and, at the same time, an exoneration of Whitman from the frequent charge that his poetry prophesies the fulfillment of the promises America held in the nineteenth century."14 Moran correctly points out Simpson's indictment of America, but his claim for an exoneration of Whitman is mistaken. In Simpson's own essay on the poem, the poet explains,

... I think that most of his prophecies have been proved wrong. It is a strange fact, when you think about it - that a poet can be great and yet be mistaken in his ideas. The Whitman who heralds an inevitable march of democracy, who praises the intelligence of the masses, is nearly always mistaken. At least, if there ever was an America like that, it no longer exists. But the Whitman who uses his own eyes and ears, who describes things, who expresses his own sly humor or pathos, is unbeatable. I tried to show the two Whitmans in my poem. I used my ideas about Whitman as a way of getting at my own ideas about America. ${ }^{15}$

It is Simpson's struggle with these two Whitmans that makes his encounter with Whitman a dynamic one. At the End of the Open Road is dominated by Simpson's attack on Whitman-as-optimist; Simpson's subsequent poetry, to a degree, recuperates Whitman by viewing him as a starting point for Simpson's own poetry of ordinary, individual lives. In At the End of the Open Road, a rescuing or redeeming Whitman is not forthcoming. Simpson hammers away at Whitman-the-mistaken-optimist, for to be joyful in modern America is to be on death's side:

Every night, at the end of America

We taste our wine, looking at the Pacific.

How sad it is, the end of America! 
While we were waiting for the land

They'd finished it - with gas drums

On the hilltops, cheap housing in the valleys

Where lives are mean and wretched.

But the banks thrive and the realtors

Rejoice-they have their America. (END, 69)

If Simpson's Whitman is at all redeemed, it is in the following acknowledgment (made near the end of "Lines Written Near San Francisco"):

Whitman was wrong about the People,

But right about himself. The land is within.

At the end of the open road we come to ourselves.

Perhaps why Simpson feels compelled to struggle with Whitman is precisely because Simpson's own (unstated) task is very close to Whitman's often stated (and in Simpson's opinion, failed or falsified) project: to be a national bard. But Simpson does not wish to lie about either the nation or its people, and so he must set aside one of the two Whitmans, Whitman-the-false-prophet, if he, Simpson, is to accomplish his own task.

If we return to Whitman's own "Song of the Open Road," we can locate aspects of Simpson's two Whitmans, and we can also begin to identify a further area of Simpson's critique of Whitman. The optimistic Whitman, the one attacked in At the End of the Open Road, dominates this poem from the opening lines:

Afoot and light-hearted I take to the open road,

Healthy, free, the world before me,

The long brown path before me leading wherever I choose.

to observations such as this:

I think heroic deeds were all conceiv'd in the open air, and all free poems also,

I think I could stop here myself and do miracles,

I think whatever I shall meet on the road I shall like, and whoever beholds me shall like me,

I think whoever I see must be happy.

It is this Whitman, the one who writes about "the progress of souls" and who sounds like a cheerleader at a pep rally for the spirit - "forever forward, I ... they go toward the best - toward something great" - who remains Simpson's whipping boy. But even in as overwhelmingly cheerful a poem as "Song of the Open Road," traces of another Whitman, one nearly ignored by Simpson and many other readers, appear: 
(Still here I carry my old delicious burdens,

I carry them, men and women, I carry them with me wherever I go,

I swear it is impossible for me to get rid of them,

I am fill'd with them, and I will fill them in return.)

There is a Whitman who admits his doubts, burdens, and failings. Too often the probable occasion for Whitman's poetry is forgotten: isn't the poet of brotherhood and the crowd also the poet struggling with his own isolation and loneliness? Isn't the poet of human perfection also one who is all too acutely aware of his own failings? "Song of the Open Road" can be read as an elaborate wish spoken by a man who hopes that "Henceforth I whimper no more, postpone no more, need nothing, / Done with indoor complaints, libraries, querulous criticisms." Whitman's poems, such as "Song of the Open Road," do not enact but hope for change: "From this hour I ordain myself loos'd of limits and imaginary lines, $/$. . divesting myself of the holds that would hold me."

The Whitman who receives Simpson's praise is the one "who uses his own eyes and ears," the poet who describes the world around him. In singling out this Whitman, Simpson agrees with F. O. Matthiessen's earlier assessment:

Yet the fact is that even though Whitman did not want to be personal, but to write poems 'with reference to ensemble,' to make his voice that of the general bard of democracy, the evidence of the poems themselves shows that he was at his best, not when he was being sweeping, but when contemplating with delicacy and tenderness some object near at hand. ${ }^{16}$

In Adventures of the Letter I (1971), the book of poems which follows At the End of Open Road (and a Selected Poems, 1965), Simpson includes "Sacred Objects," written for Whitman on the occasion of his sesquicentennial birthday celebration in 1969. The poem states succinctly the side of Whitman which attracts Simpson:

The light that shines through the Leaves is clear: 'to form individuals.'

Indeed, this formation of individuals, the particularities of an ordinary life presented at key dramatic moments, is an apt description for much of Simpson's own poetry from Adventures of the Letter I through The Best Hour of the Night (1983).

But for Simpson, Whitman's attention to individual, ordinary lives constitutes only a beginning. In "Honoring Whitman," Simpson's most recent prose assessment of Whitman, he asserts that when Whitman "looks at what he sees, he is certainly a great American poet." However, Simpson, as always, qualifies and undercuts his praise for Whitman by pointing out what his predecessor fails to accomplish: 
There are ranges of poetry that lie beyond Whitman. Of situations such as occur in people's lives he appears to have known very little, and these are our main concerns. He is good at describing shipwrecks, which are infrequent, but does not show affections, attachments, anxieties, shades of feeling, passions ... the life we actually have. (MS, 259-260)

In terms of Harold Bloom's theories of influence, Simpson's relationship to Whitman is of the tessera variety. Bloom explains that "in the tessera, the later poet provides what his imagination tells him would complete the otherwise 'truncated' precursor poem and poet" (ANX, 66). In exploring the origins of the word tessera, Bloom first quotes Jacques Lacan's translator, Anthony Wilden, then offers his own summary:

"The tessera was employed in the early mystery religions where fitting together again the two halves of a broken piece of pottery was used as a means of recognition by the initiates." In this sense of a completing link, the tessera represents any later poet's attempt to persuade himself (and us) that the precursor's Word would be worn out if not redeemed as a newly fulfilled and enlarged word of the ephebe. (ANX, 67)

Simpson's “Sacred Objects" begins:

I am taking part in a great experimentwhether writers can live peacefully in the suburbs and not be bored to death.

As Whitman said, an American muse installed amid the kitchen ware.

He grasps a shard of Whitman's pottery-the portion which directs the poet's attention to ordinary life; then, Simpson completes the vessel by going much deeper than his predecessor into the stories of individual lives. The nature of Simpson's completion, as well as of his complaint about Whitman's incomplete attention to ordinary lives, can be seen in "Honoring Whitman" when Simpson describes his predecessor's failings:

$\mathrm{He}$ is a stroller, an onlooker, a gazer, and has nothing to say about what goes on in the houses he is passing, or behind office or factory windows, or in the life of a man turning a plough. He does not seem to know what people say to each other-especially what men say to women, or women to men. (MS, 260)

More and more, Simpson's own poems, as he stated in an interview which appeared in 1976, are written "in the dramatically narrative form" (COMP, 300). Simpson concludes about Whitman, "There is hardly any drama or narration in his poetry-ideas aren't realized in action" (MS, 260).

If we return to Whitman's "Song of the Open Road," we find that most of Simpson's criticisms are sustained: 

You rows of houses! you window-pierc'd facades! you roofs!
You porches and entrances! you copings and iron guards!
You windows whose transparent shells might expose so much!
You doors and ascending steps! you arches!
You gray stones of interminable pavements! you trodden crossings!
From all that has touch'd you I believe you have imparted to yourselves, and now would impart the same secretly to me,
From the living and the dead you have peopled your impassive surfaces, and the spirits thereof would be evident and amicable with me.

Re-reading "Song of the Open Road" with Simpson's criticisms in mind, the reader finds Whitman's poem to be filled with plurals and generalizations. The poet listens to "others," he imagines himself loved by "strangers," "all seems beautiful to me," and he will scatter himself "among men and women" as he goes. Oddly enough, even the erotic moments in the poem become generalized and plural. In the seventh section, Whitman, after generalizing, does present individuals:
What is it I interchange so suddenly with strangers?
What with some driver as I ride on the seat by his side?
What with some fisherman drawing his seine by the shore as I walk by and pause?
What gives me to be free to a woman's and man's good-will? what gives them to be free to mine?

But his specificity is momentary. Simpson's own poetic project is to complete what Whitman began. Whitman pointed to the value and importance of common lives, but Simpson's effort is not to generalize but to get inside those lives through individual dramatic narratives. Indeed, that inside view is the strength of Simpson's most recent work, especially in the first and third sections of The Best Hour of the Night.

But before we accept Simpson's criticisms of Whitman as being totally accurate, we should also keep in mind Bloom's suggestion that misreading (or partial reading) is an essential part of the dynamics of poetic influence. I cannot produce scores of counter-examples from Whitman's poetry to demonstrate that he did get inside the lives of others, for on this point there is a great degree of truth to Simpson's criticism. But in "Song of the Open Road," Whitman himself is painfully aware of the fact that he remains an outsider:

\footnotetext{
Whoever you are, come forth! or man or woman come forth!

You must not stay sleeping and dallying there in the house, though you built it, or though it has been built for you.
}

Out of the dark confinement! out from behind the screen! It is useless to protest, I know all and expose it. 
Behold through you as bad as the rest,

Through the laughter, dancing, dining, supping, of people,

Inside of dresses and ornaments, inside of those wash'd and trimm'd faces,

Behold a secret silent loathing and despair.

No husband, no wife, no friend, trusted to hear the confession,

Another self, a duplicate of every/one, skulking and hiding as it goes,

Formless and wordless through the streets of the cities, polite and

bland in the parlors,

In the cars of railroads, in steamboats, in the public assembly,

Home to the houses of men and women, at the table, in the bedroom, everywhere,

Smartly attired, countenance smiling, form upright, death under the

breast-bones, hell under the skull-bones,

Under the broadcloth and gloves, under the ribbons and artificial flowers,

Keeping fair with the customs, speaking not a syllable of itself,

Speaking of any thing else but never of itself.

If Whitman observes externals, it is, as here, to urge us to shed those masks or to strip those surfaces away himself to expose the soul. Those who do not travel with him, who do not "know the universe itself as a road, as many roads, as roads for traveling souls," are condemned to limitation, "a secret silent loathing and despair," a life of quiet desperation. Such lives, in their particularity, struggle, and drama, do not seem to interest Whitman. Bloom goes so far as to conclude that all of Whitman's "wholly realized works" are "centered only on his isolate self, and on Emersonian seeing, which is not far from shamanistic practice, and has little to do with observation of externals" (ANX, 133). In his most recent essays, Bloom tells us that Whitman quite simply is the American Sublime. ${ }^{17}$

It is the sublime Whitman, following closely on the heels of the optimistic Whitman, who receives Simpson's attacks. In "Sacred Objects," Simpson, still hoping that he and Whitman can find a common ground, asks, "Where then shall we meet?" But Simpson asks the question because he wants to know how Whitman would fare in our world. In this world, where the American muse is "installed amid the kitchen ware," Simpson remarks, "and we have wonderful household appliances ... / now tell me about the poets."

In the development of Simpson's own poetic career, his encounter with Whitman in At the End of the Open Road is pivotal in two ways: stylistically, and, more important, in terms of the variety of truth-saying that will form the basis of Simpson's writing. Simpson follows Whitman's lead in exploring the texture and variety of individual lives, but with increasing emphasis he parts company with the mystical or sublime side of Whitman. By this process of exclusion and rejection, Simpson clarifies the direction of his own development. By rejecting the mystical Whitman, Simpson also symbolically resists the sixties' fashion of "deep image" poetry. By virtue of this rejection, he parts company with poets such as Bly, Kinnell, Wright, and Merwin, each of whom continues (in a different manner) to explore the deep image for another decade. Simpson's poetry, increasingly, leaves behind the 
image-based mysticism of the sixties in favor of his own variety of concise narratives. To use Whitman's metaphor, Simpson's direction is a road which goes by Chekhov's house and, increasingly, away from Whitman's. In fact, the section which immediately precedes "Sacred Objects" in Adventures of the Letter I is entitled "Looking for Chekhov's House," and the section concludes,

\author{
These idiots rule the world, \\ Chekhov knew it, and yet \\ I think he was happy, on his street. \\ People live here ... you'd be amazed.
}

"People live here" becomes the title for Simpson's Selected Poems (1949-1983), and that is his primary concern: where and how people actually live their lives. The Whitman who declares the immortality and divinity of all men and women is subject to Simpson's suspicion and, finally, rejection.

Most recently, in "Honoring Whitman," Simpson tells us,

There is the kind of reader who, having no knowledge of religion, is always looking in books for the secret of the universe. For such a one, Whitman will be mystic, together with Kahlil Gibran and the authors of pamphlets on astrology.

In so far as Whitman enthuses over "a great round wonder rolling in space" he is a rudimentary poet, the eternal sophomore enthusing over "the great ideas" and neglecting his physics lesson and his French. In so far as Whitman talks about the universe he is not worth the attention of a grown person. (MS, 258-259)

Though ultimately Simpson replaces Whitman as a mentor or guide with the more compatible figure of Chekhov, it should still be noted that Simpson is one of Whitman's heirs, especially in terms of subject matter and the desire to be a national bard. Simpson refuses to idolize his benefactor, but, in his own combative way, he honors him. In fact, Simpson pays Whitman a higher honor than hero-worship by doing battle with him, which is what the epigraph to "Honoring Whitman" indicates: "He most honors my style who learns under it how to destroy the teacher." Whitman, in "Song of Myself," seems to agree: "no friend of mine takes his ease in my chair."

For Simpson, friendship with Whitman requires opposition. As we have already seen, that opposition means debunking and re-forming our vision of Whitman. To draw on one final example of Simpson's ever-shifting reinterpretation of Whitman, it is useful to consider Simpson's remarks in an interview conducted in 1974:

Now I'm not a terribly spiritual person. I'm not a mystic. In fact, I have some very cynical moods. Therefore, what is good for me is to read people who are slightly mystical and religious and deep in that way, to use some of the control for myself. It prevents me from becoming stupid, you see. I'm sure that I'm completely different from Whitman in my likes and 
dislikes as a man. But I love Whitman, because he explores those areas I know I should be conscious of. (COMP, 270)

Here, Simpson, as Bly, Ginsberg, and others have done, proclaims Whitman as a mystic. While Simpson declares his own difference from Whitman, he also claims, "In a way I have got to keep thinking and looking for spiritual guides" (COMP, 270). But, as we shall soon find in "Searching for the Ox," Simpson thoroughly distrusts spiritual guides. The only "spirituality" palatable to Simpson is an earthly, sensual spirituality. Thus in 1981, when Simpson republishes the interview quoted above, he adds the following footnote: "Reading this six years later I cannot understand why I thought Whitman either mystical or religious. He is a naturalist throughout" (COMP, 270). Yet, a year later, in "Honoring Whitman," the mystic-Whitman, "the eternal sophomore," gets lumped with Kahlil Gibran.

In 1976 in "Rolling Up," Simpson explains his objection to mysticism: "My objection to the pursuit of esoteric knowledge, shamanism and so on, is that it neglects the life right under your nose" (COMP, 313). The title poem to Searching for the $O x$ (1976) reaches a similar conclusion:

And still, I must confess,
I fear those messieurs, like a peasant
listening to the priests talk Latin.
They will send me off to Heaven
when all I want is to live in the world.

"Searching for the Ox," Simpson's own spiritual journey, becomes an antispiritual story proclaiming the poet's renewed attachment to the earth. Though "Following in the Way / that 'regards sensory experience as relatively unimportant,' / and that aims to teach the follower / 'to renounce what one is attached to," Simpson learns the opposite:

\section{I find my awareness}

of the world-the cry of a bird, susurrus of tires, the wheezing of the man in the chair next to mehas increased.

In an interview published the same year, Simpson explains:

Poets are very different from religious people. Religious people don't need the here and now. Their object is to get away from it and to get beyond it into mystery directly. The artist is not a religious man. He may believe in religion; he may be motivated by it largely, but in the practice of his art he cannot operate the way a saint operates. The artist must cherish this world; this is what art is made of. (COMP, 292) 
In Simpson's distinction between the artist and the religious man, we can locate as well his final swerving away from Whitman's example. In a recent essay, "Reflections on Narrative Poetry," Simpson suggests that poets

may indeed learn more about writing narrative poems from the novelist than from other poets, for in the past two hundred years it has been the novelist whose labor it was to imitate life, while the poet prided himself on his originality, his remoteness from everyday life. (COMP, 346)

Thus, we should not be surprised to find that the primary muse or model for Simpson's Caviare at the Funeral (1980) is Chekhov. 'Indeed, in the book's central poem, "Why Do You Write About Russia?," the narrator, asked, "what are you reading now?," responds, "Chekhov." In Simpson's most recent collection of poems, The Best Hour of the Night, ${ }^{18}$ while oblique references to Whitman do crop up, Simpson continues to be more attracted to European prose writers, especially Proust and Chekhov. "In Otto's Basement," however, does echo the end of "Song of Myself":

So we endure it. This is what Jefferson
and Lincoln had to endure,
sitting and listening to people
argue ... the cost of conversion from oil to coal
and the statement by the tree-trimming committee.
If you want to know what freedom cost
look for us here, under the linoleum. $(\mathrm{BH}, 66)$

Simpson gauges our descent from Whitman by the difference in connotation, rhetoric, and tone between "I bequeath myself to the dirt to grow from the grass I love, / If you want me again look for me under your boot-soles" and "look for us here, under the linoleum."

If it is true that Whitman helped to turn Simpson's attention to common lives and objects, then Simpson completes the work of his predecessor by getting inside those ordinary lives. In The Best Hour of the Night, in poems such as "Physical Universe," "Quiet Desperation," and "The Previous Tenant," with Chekhovian coolness and clarity, Simpson takes the reader into painfully quotidian, suburban lives. And if his accomplishment represents a "surpassing" of Whitman, oddly enough, the central dilemma of Simpson's poetry, as he acknowledges indirectly in "The Champion Single Sculls" with its passing reference to "Song of Myself," remains a Whitmanian one:

Stillness, said a picture, is not being immobile, but a clear separation of the self from its surroundings while taking part (we must take part how else are we to live?) 
"Max Schmitt in a Single Scull" ...
A river with iron bridges ...
Schmitt is resting on his oars,
looking toward the observer,
"both in and out of the game."
Rowing! This is what I have to practice. $(\mathrm{BH}, 58)$

In writing about contemporary American life, suburban or otherwise, and its attendant "quiet desperation," the observer (or poet) will inevitably be "both in and out of the game," and rowing, or moving precisely and gracefully across the surface, is one approach to take. But that approach may be more "out of the game." Another approach is Whitman's rhetoric of solidarity and brotherhood, a stance adopted by Pablo Neruda and others. But Simpson remains skeptical because such rhetoric may be merely a posture, dishonest because the proletarian bard in contemporary America is virtually unthinkable except as a kind of confidence man. Simpson's dilemma, as I see it, remains the problem of the observer's relationship to the world he describes. To be "both in and out of the game" indeed requires great practice, delicacy, and restraint, qualities which Simpson, at present, seems to be absorbing more from Chekhov than from Whitman.

I do not think that Simpson's combat with Whitman is atypical of the process of poetic influence. Nor does the preponderance of Simpson's criticisms and rejections of his predecessor mean that Whitman's impact on Simpson is slight. Though Bloom's studies of poetic influence do get out of hand-his battles between "strong poets" verge on descriptions of tag team wrestling-his essential point, that conflict (Blake: "In opposition is true friendship") is crucial to the most important instances of influence, is correct and is borne out by a study of Simpson's relation to Whitman. As Bloom explains:

It does happen that one poet influences another, or more precisely, that one poet's poems influence the poems of the other, through a generosity of the spirit, even a shared generosity. But our easy idealism is out of place here. Where generosity is involved, the poets influenced are minor or weaker; the more generosity, and the more mutual it is, the poorer the poets involved. (ANX, 30)

Thus, Bloom, with approval, quotes Nietzsche: "'Every talent must unfold itself in fighting" (ANX, 52). As Whitman has it, "You will hardly know who I am or what I mean, / But I shall be good health to you nevertheless, I And filter and fibre your blood." Whitman, who in poems such as "Poets to Come" foresaw his own words as but beginnings, offers health to succeeding poets not merely by positive example, but by rousing the blood and the spirit of conflict in his poetic heirs.

The University of Alabama 


\section{NOTES}

1 Robert Bly, "What Whitman Did Not Give Us," in Walt Whitman: The Measure of His Song, ed. Jim Perlman, Ed Folsom, and Dan Campion (Minneapolis: Holy Cow! Press, 1981), p. 321. Since many additional references in my essay refer to essays collected in this volume, wherever possible subsequent references will be abbreviated parenthetically, MS, followed by the appropriate page number.

2 The best guide to recent reactions, salutes, arguments, and dialogues with Walt Whitman is Walt Whitman: The Measure of His Song, which includes poems and essays by Ginsberg, Bly, James Wright, Simpson, Ignatow, Kinnell, and others.

3 Harold Bloom, Agon: Towards a Theory of Revisionism (New York: Oxford University Press, 1982), p. 183.

4 Ed Folsom, "Talking Back to Walt Whitman: An Introduction," in Walt Whitman: The Measure of His Song, pp. xxi-xxii.

5 A Dream of Governors, p. 15. Since frequent references to Louis Simpson's poetry will occur throughout my essay, the following editions and abbreviations are used: Good News of Death and Other Poems in Poets of Today II (New York: Charles Scribner's Sons, 1955), pp. 149-195, GND. A Dream of Governors (Middletown, Connecticut: Wesleyan University Press, 1959), DREAM. At the End of the Open Road (Middletown, Connecticut: Wesleyan University Press, 1963), END. Adventures of the Letter I (New York: Harper \& Row, 1971), ADV. Searching for the Ox (New York: William Morrow, 1976), OX. Caviare at the Funeral (New York: Franklin Watts, 1980), CAV.

6 A Company of Poets, p. 32. Many of Simpson's essays, reviews, and interviews are collected in this volume, $A$ Company of Poets (Ann Arbor, Michigan: The University of Michigan Press, 1981). Subsequent references, wherever possible, will be abbreviated parenthetically, $\mathrm{COMP}$, followed by the appropriate page number.

7 F. O. Matthiessen, American Renaissance: Art and Expression in the Age of Emerson and Whitman (New York: Oxford University Press, 1941), p. 633.

8 North of Famaica (New York: Harper \& Row, 1972), p. 222, as cited by George S. Lensing and Ronald Moran, Four Poets of the Emotive Imagination: Robert Bly, fames Wright, Louis Simpson, and William Stafford (Baton Rouge: Louisiana State University Press, 1976), p. 165.

9 Harold Bloom, The Anxiety of Influence: A Theory of Poetry (New York: Oxford University Press, 1973), p. 5. Subsequent references to this book will be abbreviated ANX, followed by the appropriate page number.

10 Walt Whitman, Prose Works 1892, ed. Floyd Stovall (New York: New York University Press, 1964), 2:369-370.

11 Justin Kaplan, Walt Whitman: A Life(New York: Simon and Schuster, 1980), p. 337.

12 As for the importance of these Whitman-poems to Simpson's overall development, a strong, if somewhat indirect, argument can be made on the basis of Simpson's forthcoming People Live Here: Selected Poems 1949-1983 (BOA Editions) where "On the Lawn at the Villa," "Walt Whitman at Bear Mountain," "In California," "Lines Written Near San Francisco," and "Sacred Objects" are all included in the selections made by the author.

13 Company, p. 37. In a more recent essay (1977), Simpson again addresses the problem of audience, but this time in relation to his own work: "This brings us to the question, 'Whom do you visualize as your reader?' It's a touchy question. I certainly don't write for people who read Rod McKuen. Nor for people who want political poetry. In fact, as far as I can see, 
I have few readers. On the other hand, my poems have been translated into some nine foreign languages and have been taught in schools in Africa, in Macedonia, and other places. I guess I am writing for readers in the United States in the future." (COMP, 326)

14 Ronald Moran, Louis Simpson (New York: Twayne Publishers, 1972), p. 112.

15 Company, p. 34. In an interview printed in 1979, Simpson reiterates his theory of two Whitmans present in At the End of the Open Road: "What I was attacking in Whitman there was one side of Whitman. There are two Whitmans as I see it. And the side I attacked was his expansionist, materialist, 1880s Gilded Age side in which Whitman was hailing the advance of the railroad, the advance of the American prosperity. That was a public Whitman used by other people and that was the side I was attacking in him and in America generally." (COMP, 328)

16 F. O. Matthiessen, American Renaissance, pp. 546-547.

17 Harold Bloom, Agon, p. 182.

18 Subsequent references to The Best Hour of the Night (New Haven and New York: Ticknor and Fields, 1983) will be abbreviated, $\mathrm{BH}$, followed by the appropriate page number. I am grateful to Louis Simpson for sending me a manuscript copy of Best Hour well before the book's publication. 